\author{
REVIEW OF EUROPEAN AND COMPARATIVE LAW \\ VOLUME XLVII \\ YEAR 2021, ISSUE 4 pp. 67-81 \\ DOI: https://doi.org/10.31743/recl.12859
}

\title{
SUCCESSION OF DIGITAL GOODS. A COMPARATIVE LEGAL STUDY
}

\author{
Mariusz Fras ${ }^{*}$
}

\begin{abstract}
The purpose of this article is to present possible solutions to the problem of access to digital contents left by a deceased user of Internet services under different European legal systems. Discussion of this issue from a comparative perspective will allow the drawing of general conclusions about the direction de lege lata in which European legislation is heading. In my opinion there should be dedicated legal provisons introduced into the polish civil code which would pertain to digital goods. This would also facilitate the harmonization of inheritance matters in a European perspective. Technological development requires amending the civil code to fit changing reality.
\end{abstract}

Keywords: digital content, digital state, Facebook, strictly personal rights, heirs

\section{INTRODUCTION}

Information technologies have contributed to significant changes in economy, law and society itself, whose essential part is currently formed by the so-called digital generation (digital natives). Contemporary services

This contribution was written in the framework of research project 2020/39/B/HS5/02631 funded by the National Science Centre in Poland.

Dr. habil. Mariusz Fras, Associate Professor, Faculty of Law and Administration, University of Silesia; correspondence address: ul. Kochanowski 6/1, 40-035 Katowice, Poland; e-mail: kancelaria-fras@o2.pl; https://orcid.org/0000-0002-0033-6909. 
on the internet enable their users to actively create new digital content. As a result, such users produce, use and record huge amounts of data. Therefore, the question becomes relevant about the future of such content and the right to dispose of them in the event of "digital death," that is death of an Internet user ${ }^{1}$.

The purpose of this article is to present possible solutions to the problem of access to digital content left by a deceased user of Internet services under different European legal systems. Discussion of that issue from a comparative perspective will allow to draw general conclusions about the direction de lege lata in which European legislation is heading.

\section{DEFINITION OF DIGITAL GOODS}

In order to fully understand the problems of admissibility of inheriting digital goods, in the first place one should consider the very concept discussed here, as an element of the deceased person's succession estate.

It must be strongly emphasized that digital goods are often understood differently in the normative instruments of particular countries or, oftentimes, they are not defined at all by the legislator in a given national legal system. The legislative chaos arising in that regard may, in future, lead to countless conflicts between heirs (future or present), possible heirs and service providers of particular content rendered by electronic means, who frequently base their activities and proposed solutions on the provisions applicable in the country of their domicile, which does not have to correspond to the legal regime applicable at the place of residence of the recipients of services.

Having the above in mind, at the beginning, one should quote the provision of Art. 2 item 5 of the Act on consumer rights ${ }^{2}$, where digital content was defined by the Polish legislator as data produced and supplied in digital form. The above provision is an implementation of the Directive of

1 Anetta Breczko and Marta Andruszkiewicz, "Prawo spadkowe w obliczu postępu technologicznego (nowe wyzwania w XXI wieku)," Biatostockie Studia Prawnicze 22, no. 2 (2017).

2 Act of 30 May 2014 on consumer rights (i.e. Dz. U. 2020 r. poz. 287). 
the European Parliament and of the Council of $2011^{3}$ on consumer rights. In turn, under Recital 19 of the cited Directive, Digital content means data which are produced and supplied in digital form, such as computer programs, applications, games, music, videos or texts, irrespective of whether they are accessed through downloading or streaming, from a tangible medium or through any other means.

At the time being, however, there is no uniform and consistent, for all Member States of the EU, definition of the term "digital goods". Certain authors point to the need to differentiate between both the above terms, treating digital goods as a concept with much broader meaning than digital content, covering as well the right of access to such content, the right of their creation or to use a virtual account ${ }^{4}$. In the author's opinion, the position should be considered correct according to which one can use the cited terms interchangeably since the very general nature of the statutory definition of digital content allows to qualify the concept of digital goods as included in the cited formula. Therefore, for the purposes of this study, I have adopted the latter of the indicated understandings of digital content.

However, in the context of the above, it becomes necessary to point out that digital goods are characterized primarily by their wide variety, deriving in the first place from the multiformity of services rendered by electronic means. Those contents may fall under such categories as email accounts, virtual currencies, musical works in digital format, e-books or, which is most important for the present considerations, social networking accounts. From the point of view of such wide diversity, one should agree with the position that the currently applicable legal provisions of Polish succession law should not be, at the time being, indiscriminately referred

3 Directive of the European Parliament and of the Council 2011/83/UE of 25 October 2011 (OJ EU L 2011.304.64).

4 Paweł Szulewski, "Śmierć 2.0 - problematyka dóbr cyfrowych post mortem," in Non omnis moriar. Osobiste i majątkowe aspekty prawne śmierci cztowieka. Zagadnienia wybrane, ed. Jacek Gołaczyński, Jacek Mazurkiewicz, Jarosław Turłukowski, and Daniel Karkut (Wrocław: Oficyna Prawnicza, 2015), 734

5 Mateusz Mądel, "Dostęp do treści cyfrowych zmarłego użytkownika usług internetowych na tle orzeczenia Federalnego Trybunału Sprawiedliwości w Niemczech," Transformacje Prawa Prywatnego 2 (2020): 126. 
to all the listed categories of digital goods in a general and abstract manner, and this is the case because of the heterogeneous nature of each of those contents ${ }^{6}$. Differing views of Polish academic authors in that respect and practically undeveloped position of the judiciary ${ }^{7}$ led to the need to reach for a breakthrough, from the point of view of the present considerations, judgment of the Federal Court of Justice in Germany (Bundesgerichtshof) of $2018^{8}$. The Court resolved a case, which had been pending for several years, concerning the possibility of inheriting an account of a minor user of the social networking portal Facebook.com by her ascendents, namely parents.

\section{THE GERMAN BUNDESGERICHTSHOF'S DECISION ON ACCESS TO THE FACEBOOK ACCOUNT OF A DECEASED CHILD}

In the decision delivered by the Federal Court of Justice in Germany, it was strongly indicated that in case of death of an owner of a social networking account, the user's contract passes to the user's heirs under $\$ 1922$ BGB $^{9}$. In a thesis presented by the Court, it was also pointed out that access to a user account and the communication contents kept in that account does not violate post mortem personal rights of the deceased or the right to the protection of personal data or secrecy of correspondence. It must be noted that the cited ruling admits as well the possibility to inherit

6 Anna Wszołek, "Między Facebookiem a Instagramem. Wirtualny wizerunek czy prawo majątkowe? - analiza dóbr cyfrowych in concreto," Internetowy Przegląd Prawniczy TBSP UJ 3 (2017): 131.

7 Mariusz Załucki, ed., Kodeks cywilny. Komentarz. Wyd. 2 (Warsaw: Legalis, 2019).

8 Judgment of the Federal Court of Justice in Germany of 12 July 2018, III ZR 183/17, accessed June 16, 2021, https://juris.bundesgerichtshof.de/cgi-bin/rechtsprechung/document.py?Gericht=bgh\&Art=en \&nr=86602\&pos=0\&anz=1.

9 German Civil Code of 18 August 1896 (BGB - Bürgerliches Gesetzbuch, BGBl I S. 42, FNA 400-2), accessed June 16, 2021, http://www.gesetze-im-internet.de/bundesrecht/bgb/gesamt.pdf.

$\$ 1922(1)$ BGB provides that upon the death of a person (devolution of an inheritance), that person's property (inheritance) passes as a whole to one or more than one other persons (heirs). ("Mit dem Tode einer Person (Erbfall) geht deren Vermögen (Erbschaft) als Ganzes auf eine oder mehrere andere Personen (Erben) über”). 
the entire Internet account left by a deceased user, and not only the digital content kept on the account. The difference in this case is fundamental. Succession of an entire portal account left by a deceased user offers the possibility of further use of the account in the same way as the deceased user did. On the other hand, succession of digital accounts would only allow to obtain access to the goods kept in the portal, however, without the possibility of further using the account, that is enjoying all of its functions by the heirs - as in the case of living and active portal users.

To recall the factual background of the decision cited above, it must be pointed out that the dispute relating to the succession of digital contents left by a late user of Internet services related to the deceased person's Facebook account. Parents of a fifteen year old deceased girl, by gaining access to their daughter's Internet account on Facebook, wanted to clarify the circumstances of her death. The conclusion of the official investigation was that the deceased died as a result of injuries sustained in an accident at a subway station. However, based on the digital contents kept on the Internet account, taking into consideration the correspondence gathered in the account, the heirs of the deceased wanted to learn if she had committed suicide or if it had been only an unfortunate accident. However, the portal's administrator refused the heirs' access to the deceased person's Internet account, by blocking access to that account and changing its status to in memoriam ${ }^{10}$. It must be noted that the above-mentioned status disabled the heirs to log in to the account using the access data (login and password) used by their deceased daughter during her life. Interestingly enough, after changing the account's status to in memoriam, the parents of the deceased, as her only heirs, did not have the access to the contents stored in the account - except for conversations in which they took part themselves - whereas partners in communication (the deceased girl's friends) had such possibility. Because of the above, the heirs asserted a claim against the portal's administrator for a grant of access to the user's full account and the data stored in the account, including to the recorded communication contents. On the contrary, the portal's administrator, justifying the refusal to provide the heirs with access to the deceased user's

10 Mateusz Mądel, Następstwo prawne treści cyfrowych na wypadek śmierci (Warsaw: C.H. Beck, 2018), 92-93. 
account, argued that it was necessary to protect personal interests, personal data of the original user, secrecy of correspondence of that late user and to protect data of other users of the portal as her partners in communication. All the doubts cited above were resolved in the course of further proceedings, and the final position in that matter was taken by the Federal Court of Justice in Germany.

Adjudicating in the first instance, the Land Court in Berlin concluded that under $\$ 1922$ BGB (which, in the Polish context, would be, as it were, an equivalent of Art. $922 \mathrm{CC}^{11}$ ) the "property" accumulated on the service provider's servers did not pass to the heirs, however, the heirs inherited the right of access to the servers under the original contract concluded between the deceased and the service provider ${ }^{12}$. In the justification of the judgment, it was highlighted that the legal relationship originally binding between the deceased and the service provider was "property" in the understanding of 1922 BGB. At the same time, it was excluded that the rights and obligations under the contract between a portal's user and the service provider were strictly linked to the deceased person. The position expressed by the court was justified by the lack of any exact verification by Facebook of the user's identity when the account had been created. In consequence, it was concluded that the Terms and Conditions on the personal nature of an account were not binding. In the opinion of the court, in the examined case there was also no infringement of the personal data of partners in communication. It was pointed out that in situations when an account is taken over by heirs through universal succession, under $\$ 1922$ BGB, there is no interference with third party rights, as in the case of inheritance by legal successors of traditional correspondence. The position taken by the I instance court was not accepted by the service provider, who appealed against the decision, and as a result of appellate proceedings, the court's position changed and the heirs' claims were dismissed.

11 See Art. $922 \$ 1$ and 2 of the Polish Civil Code: " $\$ 1$.Property rights and obligations of the deceased pass, upon his death, to one or several persons in accordance with the provisions of this book. $\$ 2$. Succession does not include the deceased person's rights and obligations that are strictly and personally related to him or rights which, on his death, pass to specified persons irrespective of whether they are heirs."

12 See the judgment of the Land Court in Berlin of 17 December 2016, 20 O 172/15, accessed June 16, 2021, https://dejure.org/ext/f551ef3d8be146b2dca4a1011db1feca. 
The II instance court emphasized that it was possible to conclude that the heirs entered into the rights and obligations under the contract but not in a sense permitting active use of the social networking account, that is in a manner enjoyed by the deceased person, but in a passive way, consisting in the possibility to view the digital contents stored in the account ${ }^{13}$. It was also emphasized that it was inadmissible for the heirs to obtain access to the deceased person's account because of the provisions of telecommunications law and norms of the Constitution ${ }^{14}$. Under Art 10(1) of the Constitution of the Federal Republic of Germany (GG), the privacy of correspondence, posts and telecommunications are inviolable. On top of that, Art. 10(2) GG provides that any restrictions of those rights may be ordered only pursuant to a statutory law.

In the opinion of the Federal Court of Justice, such claim is hereditary and not precluded by the post mortem right to the protection of personal interests, secrecy of correspondence, provisions on the protection of personal data or the right to protect personal interests of partners in communication. It was emphasized that the heirs' claim followed from the contract transferred to them, concluded inter vivos between the deceased minor and the administrator of the Facebook portal. In the justification of the judgment, it was pointed out that in the contract between the deceased and the portal's administrator the possibility was not excluded of the heirs entering into the rights and obligations of the former. In the opinion of the Federal Court, the provisions of the contract were irrelevant in the examined case providing that the user must maintain the account under the user's real name and surname, or that the user shall not pass the user's access data to other individuals. It was pointed out that the cited contractual provisions related to the behaviour of the original user of the account during her life and, in the same way, did not refer to the account's fate post mortem. ${ }^{15}$

13 See the judgment of the Land Court in Berlin of 31 May 2017, 21 U 9/16, accessed June 16, 2021, https://dejure.org/ext/1792778f38a579e9316dccd9d7a6e5f4.

14 Constitution of the Federal Republic of Germany of 23 May 1949, accessed June 9, 2021, https://www.gesetze-im-internet.de/gg/.

15 The discussed ruling left undecided and open the question of the possibility of excluding heredity of an Internet account under a contract. 
The portal's administrator was compared to a postal operator, who is responsible only for placing a letter in the appropriate box but cannot be accountable for whether the person specified as addressee reads the letter or shows it to a third party. The Federal Court concluded that for a conscious user of the Internet it is obvious that, upon sending a message, the user is no longer in control of who learns about the message's content, with whom the message will be shared, and that the sender of the communication may not request its return once it has been posted. Since partners in communication assume the risk that third parties may gain access to the contents stored in the account, they should, all the more so, take into consideration that the access to the contents might be obtained by the user's heirs.

In the justification of the ruling, the Court undertook also to resolve questions relating to an attempt to distinguish between inheriting an account on the portal and inheriting only its substance, that is the digital content stored in that account. It was emphasized in the judgment that under German law it is not justified to inherit only specific digital content according to the division into material content and specifically personal content. It was concluded that in such event the same category of digital contents (e.g. messages) would be split so that communications relating to property rights exchanged through the website would be hereditary and messages unrelated to property rights would not constitute a part of the inheritance. In support of the above, it was indicated that heirs enter into the deceased person's legal position also when a legal relationship includes strictly personal contents irrespective of their material value. At this point, the Court relied on $\$ 2047(2)$ BGB and $\$ 2373$, second sentence, BGB ${ }^{16}$, providing for the inclusion in the succession estate of strictly personal

16 Under $\$ 2047(2)$ BGB, Documents relating to the personal circumstances of the deceased or of his family or to the whole estate remain joint property (Schriftstücke, die sich auf die persönlichen Verhältnisse des Erblassers, auf dessen Familie oder auf den ganzen Nachlass beziehen, bleiben gemeinschaftlich). Under $\$ 2373$ BGB, a share of the inheritance that devolves upon the seller after the completion of the sale, by subsequent succession or as a result of a person ceasing to be a co-heir, and a preferential legacy given to the seller are, in case of doubt, not to be deemed included in the sale. The same applies to family papers and family pictures. (In Erbteil, der dem Verkäufer nach dem Abschluss des Kaufs durch Nacherbfolge oder infolge des Wegfalls eines Miterben anfällt, sowie ein dem 
goods, including documents, souvenirs, photographs, etc., among which the Court included also strictly personal digital content produced within the framework of obligational relationships to which the deceased was a party. In support of the above position, it was also indicated that the differentiation between strictly personal and other content would give rise to practical problems impossible to overcome.

In the justification of the decision, the Court referred also to the possibility of violating the right to the protection of personal data by providing the heirs with access to the deceased person's account in the context of the provisions of the Regulation (EU) 2016/679 of the European Parliament and of the Council of 27 April 2016 on the protection of natural persons with regard to the processing of personal data and on the free movement of such data, and repealing Directive 95/46/EC (General Data Protection Regulation $)^{17}$ - GDPR. In response to the service provider's objection, it was pointed out that rights relating to the protection of the deceased person's personal data would not be infringed since in the examined case the service provider was not bound by the provisions of the Regulation. It was justly highlighted that the Regulation applies only to living persons. In the context of the possibility of the service provider's violation of the provisions of the Regulation in relation to partners in communication, it was concluded that in the discussed case their rights would not be infringed. Again, at this point the Court distinguished between the existence of the contract and the related account, on one hand, and the deceased person, on the other. It was emphasized that in spite of death of the person originally entitled to use the account, the account still exists after her death, and her heir becomes the person entitled to use the account. By recalling Art. 6(1) letter b GDPR, it was concluded that processing of personal data was necessary for further performance of the contract since, as a result of its performance, the service provider sends messages and other digital content between the accounts of the website's

Verkäufer zugewendetes Vorausvermächtnis ist im Zweifel nicht als mitverkauft anzusehen. Das Gleiche gilt von Familienpapieren und Familienbildern).

17 The Regulation (EU) 2016/679 of the European Parliament and of the Council of 27 April 2016 on the protection of natural persons with regard to the processing of personal data and on the free movement of such data, and repealing Directive 95/46/EC (General Data Protection Regulation) (OJ L 119, p. 1, with rectification). 
users. Therefore, processing of personal data by the portal's administrator as a part of the existing obligational relationship was considered legitimate.

\section{INHERITABILITY OF DIGITAL CONTENT UNDER POLISH LAW}

The parties' obligations were not specifically personal, which was to be an argument for the hereditary nature of the rights and obligations under the contract. It should be noted that the position presented in the justification may be difficult to defend in the context of Polish succession law. It must be emphasized that under Art. $922 \$ 2$ CC, succession does not include the deceased person's rights and obligations that are strictly and personally related to him or rights which, on his death, pass to specified persons irrespective of whether they are heirs ${ }^{18}$.

In Polish legislation no special provisions have been envisaged with regard to inheriting documents, souvenirs, photographs, etc. This is why in such situations the general provision under Art 922 CC should apply. However, doubts seem legitimate as expressed by the German Federal Court of Justice in respect of the possibility of a dichotomous division of digital goods into those serving strictly personal purposes and those serving only legal and material purposes. Such distinction would require specific investigation into all existing and possible future digital content, and their classification according to the criterion presented above. However, this is not possible because of their very wide diversity and the fact that new forms still keep emerging. It must be stressed that the problem was noticed not only in the context of German law. In Polish conditions, based on the currently applicable provisions, one should always examine the character and nature of digital contents for the purpose of their classification under Art. $992 \mathrm{CC}^{19}$.

18 Mateusz Mądel, “Dostęp do treści cyfrowych zmarłego użytkownika usług internetowych na tle orzeczenia Federalnego Trybunału Sprawiedliwości w Niemczech," Transformacje Prawa Prywatnego 2 (2020): 137.

19 Mądel, "Dostęp do treści cyfrowych zmarłego użytkownika," 140. 


\section{INHERITABILITY OF DIGITAL CONTENT FROM OTHER COUNTRIES' POINT OF VIEW}

Austrian inheritance law is covered by $₫ 531$ ABGB to $\$ 824$ Civil Code (Allgemeines bürgerliches Gesetzbuch, ABGB) ${ }^{20}$ Pursuant to $\$ 531 \mathrm{ABGB}$, the rights and obligations of deceased person constitute their estate, unless they are of a strictly personal nature. This definition of estate does not make a distinction between digital or non-digital (analog) content. The question of whether digital content is inheritable (i.e. whether parents can access the Facebook account of their deceased daughter or not) depends on whether the underlying rights of legal relationships are classified as strictly personal under the exception in $\$ 531 \mathrm{ABGB} .{ }^{21} \mathrm{Al}$ though $\$ 531 \mathrm{ABGB}$ does not contain a list of inheritable and non-inheritable rights and obligations, it does specify the decisive criterion: strictly personal nature. $\$ 1448 \mathrm{ABGB}$ is of similar nature when stating that death only terminates those rights and obligations that are limited to a person or relate to individual acts of the deceased. $\$ 1393$ sentence 2 ABGB also refers to the strictly personal nature of rights, providing that rights which relate to a person and hence terminate with him or her, cannot be assigned. Furthermore, $\$ 1171$ ABGB provides that a contract for service relating to works, for which the specific individual qualities of the contractor are essential, expires upon his death ${ }^{22}$. Contracts with providers of digital content or digital services are inheritable according to the general rule laid down in $\$ 531$ ABGB. However, rights and obligations are non-inheritable when the replacement of an obligation or obligator by an heir would change the performance of the obligation; then they are of a strictly personal nature. One has to look at each case individually, but in general, contracts with providers of digital content or digital services are not strictly personal and thus inheritable. Telecommunications and data protection law does not prevent the heirs' access either. Even if content is

20 See https://www.ris.bka.gv.at/GeltendeFassung.wxe?Abfrage=Bundesnormen \&Gesetzesnummer=10001622, accessed June 16, 2021.

21 Joachim Pierer, "Inheritability of Digital Content under Austrian Law," European Review of Private Law 27, no. 5 (2019): 1119.

22 Pierer, "Inheritability of Digital Content," 1120. 
non-inheritable, heirs would get access if they have a compelling reason that overrides the deceased's interest in privacy ${ }^{23}$.

Under Belgian law the rights that the deceased girl derived from her contract with Facebook would be inherited by her parents. Article 724 of the Belgian Civil Code (hereafter: CC) provides that by law the deceased's heirs are put in possession of his or her goods, rights and claims. It must be noted that the word 'possession' in the article lacks accuracy, because the heirs do not become mere possessors of these assets: they acquire full ownership of them, by means of substitution to be precise ${ }^{24}$. Digital rights are part of the girl's estate, because they were not established for her lifetime only nor do they originate from an intuit personae contract. Moreover, Facebook's rules on memorialized estates were found not to apply to the aforementioned contract under Belgian law. In the second part of this article, a number of legal grounds that might prevent the rights from being inherited were elaborated on. The focus of the discussion was on the Electronic Communications Act of 13 June 2005, Article 29 of the Belgian Constitution, which protects the confidentiality of the mail, and the GDPR. With regard to each of these legal grounds the answer to the question whether it prevents the parents from inheriting their daughter's rights under the contract with Facebook appears to be same: it depends on the outcome of a balancing test in which the rights and interests of the parents are balanced against the rights and interests of the communication partners of their daughter ${ }^{25}$.

Now we must describe The German Bundesgerichtshof's Decision on Access to the Facebook Account of Your Deceased Child from a Dutch Law Point of View. The discussion deals with the important question of how 'open' the system of Dutch property law is. Article 3:1 od the Dutch

23 Pierer, "Inheritability of Digital Content," 1129.

24 See art. 724 of the Belgian Civil Code: "Les héritiers sont saisis de plein droit des biens, droits et actions du défunt, sous l'obligation d'acquitter toutes les charges de la succession. L'Etat doit se faire envoyer en possession par justice, dans les formes déterminées ci-après."; https://ihl-databases.icrc.org/applic/ihl/ihl-nat.nsf/0/60a09398940a143bc1256e700032d7bb/\$FILE/code_civil.PDF, accessed June 18, 2021.

25 K.K.E.C.T. Swinnen, "The German Bundesgerichtshof's Decision on Access to the Facebook Account of Your Deceased Child from a Belgian Law Point of View," European Review of Private Law 5 (2019): 1148. 
Civil Code (DCC) defines 'goods' (goederen) as either 'things', meaning corporal objects (zaken, Art. 3:2 DCC), or as vermogensrechten (Art. 3:6 DCC $)^{26}$. Some of the Dutch scholars tell that an online account is a personal right that does not pass on to the heir. They argue that it is useless for an heir to continue the deceased's account, and moreover, that the deceased protected his account with a password, making it unlikely he would want his heirs to be able to access it. Others see no obstacle in the nature of the contract ${ }^{27}$.

Article 659 of the Spanish Civil Code deems an inheritance to comprise all assets, rights and obligations that are transferable, whether financial or personal in nature. In addition, as the universal successor, the heir takes over the legal positions held by the testator in the host of legal relationships that comprise the inheritance (Art. 661 of the CC) ${ }^{28}$. According to Spanish researchers highly similar reasoning the Spanish High Court could have reached the same decision as the BGH. In short, what it does is apply the principle of functional equivalence between the analogue and the digital world, without expressly stating so, when throughout its arguments it compares the sending of a letter by post, for example, to the sending of information via a personal account on a social network to other registered users; or, for inheritance purposes, when it compares a bank account to a personal account on a social network or a telephone communication with a different communication made using electronic means ${ }^{29}$.

26 See art. 3:6 of the Dutch Civil Code: “"Ejendomsrettigheder” er rettigheder, som enten hver for sig eller sammen med en anden rettighed kan overdrages, eller som har til formål at give indehaveren en væsentlig fordel, eller som opnås til gengæld for levering eller udsigt til fortsat at levere en væsentlig fordel.", http://www.dutchcivillaw.com/civilcodebook033.htm, accessed June 18, 2021.

27 Valérie Tweehuysen, "Digital Afterlife Under Dutch Law: The German Case on Inheriting a Facebook Account From a Dutch Perspective," European Review of Private Law 5 (2019): 1150-53.

28 See art. 659 of the Spanish Civil Code: "An estate comprises all properties, rights and obligations pertaining to a person, unless they are extinguished as a result of his death.", https://www.mjusticia.gob.es/es/AreaTematica/DocumentacionPublicaciones/ Documents/Spanish\%20Civil\%20Code.pdf, accessed June 18, 2021.

29 Susana Navas, "Digital Content of the Inheritance: Remarks on the Judgement of the German Federal Court of Justice (BGH) of 12 July 2018 from Standpoint of Spanish Law," European Review of Private Law 5 (2019): 1169. 


\section{CONCLUSION}

The indicated analyses of foreign legal systems prove that in the Member States there is no uniform position concerning succession of digital goods. One should agree with the correct view that digital contents, upon death of the user of Internet services, should not be erased, left to themselves or to the good will of the administrators of Internet portals. Therefore, the question must be asked what to do with an account and digital content upon death of a user of Internet services. It must be noted that practice looks different in that regard, however, it can generally be divided into three models. The first variant assumes that the account and the digital contents stored in the account are erased upon death of the user of the service. The second method of proceeding implies suspension/archiving of the account and the related digital contents upon the user's death. Finally, the third model assumes a transfer of rights to the account or digital contents to the heirs, close persons or a specific person appointed during the lifetime of the user of Internet services ${ }^{30}$.

In my opinion there should be dedicated legal provisions introduced into the civil code which would pertain to digital goods. This would also facilitate the harmonization of inheritance matters in a European perspective. Technological development requires amending the civil code to fit changing reality.

\section{REFERENCES}

Breczko, Anetta, and Marta Andruszkiewicz. "Prawo spadkowe w obliczu postępu technologicznego (nowe wyzwania w XXI wieku)." Biatostockie Studia Prawnicze 22, no. 2 (2017): 27-46.

Mądel, Mateusz. "Dostęp do treści cyfrowych zmarłego użytkownika usług internetowych na tle orzeczenia Federalnego Trybunału Sprawiedliwości w Niemczech.” Transformacje Prawa Prywatnego 2 (2020): 125-44.

Mądel, Mateusz. Następstwo prawne treści cyfrowych na wypadek śmierci. Warsaw: C.H. Beck, 2018.

30 Mateusz Mądel, Następstwo prawne treści cyfrowych na wypadek śmierci (Warsaw: C.H. Beck, 2018), 247. 
Navas, Susana. "Digital Content of the Inheritance: Remarks on the Judgement of the German Federal Court of Justice (BGH) of 12 July 2018 from Standpoint of Spanish Law." European Review of Private Law 5 (2019): 1159-68.

Pierer, Joachim. "Inheritability of Digital Content under Austrian Law." European Review of Private Law 27, no. 5 (2019): 1115-29.

Swinnen, K.K.E.C.T. "The German Bundesgerichtshof's Decision on Access to the Facebook Account of Your Deceased Child from a Belgian Law Point of View." European Review of Private Law 27, no. 5 (2019): 1131-48.

Szulewski, Paweł. "Śmierć 2.0 - problematyka dóbr cyfrowych post mortem." In Non omnis moriar. Osobiste i majątkowe aspekty prawne śmierci cztowieka. Zagadnienia wybrane, edited by Jacek Gołaczyński, Jacek Mazurkiewicz, Jarosław Turłukowski, and Daniel Karkut, 730-749. Wrocław: Oficyna Prawnicza, 2015.

Tweehuysen, Valérie. "Digital Afterlife Under Dutch Law: The German Case on Inheriting a Facebook Account From a Dutch Perspective." European Review of Private 27, no. 5 (2019): 1149-1158.

Wszołek, Anna. "Między Facebookiem a Instagramem. Wirtualny wizerunek czy prawo majątkowe? - analiza dóbr cyfrowych in concreto." Internetowy Przeglad Prawniczy TBSP UJ 3 (2017): 130-140.

Załucki, Mariusz. Kodeks cywilny. Komentarz. Wyd. 2. Warsaw: Legalis, 2019. 
